\title{
Cytoplasmic binding of oestradiol-17 $\beta$ in several brain regions, pituitary and uterus of ferrets ovariectomized while in or out of oestrus
}

\author{
M. J. Baum* and P. J. M. Schretlen \\ Department of Endocrinology, Growth \& Reproduction, Faculty of Medicine, \\ Erasmus University, Rotterdam, The Netherlands
}

\begin{abstract}
Summary. The reproductive status at the time of ovariectomy had no effect on oestradiol binding. In both groups of ferrets the oestradiol binding capacity of the uterus was approximately 10 times greater than that of the other tissues studied; of these other tissues the highest oestradiol binding capacity was present in the pituitary, followed by hypothalamus, midbrain, amygdala and cerebral cortex. The binding affinity of hypothalamic receptors for oestradiol was the same in ferrets which had been previously ovariectomized while either in oestrus or anoestrus. It is suggested that the occurrence of seasonal oestrus does not depend on changes in the binding capacity or affinity of hypothalamic receptors for oestradiol.
\end{abstract}

\section{Introduction}

Female ferrets kept in the northern hemisphere under natural lighting conditions come into oestrus in the spring as the days become longer; likewise, exposing anoestrous ferrets to artificial long days (14-16 h light/day) in the autumn also induces oestrus reliably within 4-8 weeks (Bissonette, 1932; Hammond, Jr, 1954). One hypothesis which has been advanced to explain the onset of oestrus in seasonal breeders postulates that neurones in the hypothalamus or in other forebrain sites which normally inhibit the secretion of luteinizing hormone-releasing hormone (LH-RH) somehow become less sensitive to the inhibitory feedback effects of the low levels of oestrogen which circulate even during the anoestrum (Donovan \& van der Werff ten Bosch, 1965; Donovan, 1967). The resetting of the brain "gonadostat" results in increased secretion of LH-RH, FSH, LH and ovarian oestradiol, which ultimately causes the physiological and behavioural changes associated with oestrus.

Much evidence suggests that for oestradiol to affect the biological activities of target cells, specific, high-affinity binding of the steroid by cytoplasmic receptor molecules is required (Jensen \& DeSombre, 1973). It seemed possible that changes in the binding capacity or affinity of oestradiol receptors in neurones which mediate the inhibitory feedback effects of this steroid on LH-RH secretion could constitute the postulated resetting of the brain "gonadostat". Wise, Payne, Karsch \& Jaffe (1975) reported that in the anterior pituitary of female sheep the concentration of cytoplasmic binding sites for oestradiol was lower during the breeding season than during the anoestrum, whereas the association constant for oestradiol and its receptor was higher during oestrus. Since all the sheep were ovariectomized 2 weeks before death, seasonal differences in circulating levels of ovarian hormones at the time of death could not have caused

* Present address and address for correspondence: Room 37-327, Massachusetts Institute of Technology, Cambridge, MA 02139, U.S.A. 
these effects. Unfortunately, however, Wise et al. (1975) presented no information about hypothalamic binding of oestradiol.

Morrell, Ballin \& Pfaff (1977) have used autoradiography to monitor the uptake of $\left[{ }^{3} \mathrm{H}\right]$ oestradiol into the brains of female mink (Mustela vison) which had previously been ovariectomized while in oestrus or anoestrus. Neurones containing radioactive label were present in the hypothalamus and in limbic forebrain structures of all the mink and there were no differences in the number of labelled cells in various forebrain regions and pituitary in oestrous and anoestrous animals. This problem was explored further in the present study, which was carried out using another seasonally breeding mustelid species, the ferret (Mustela furo). Biochemical methods were used to compare the binding capacity and affinity of neural receptors for oestradiol during oestrus and anoestrus.

\section{Materials and Methods}

\section{Animals}

Female ferrets were purchased in July from A. S. Roe, Thetford, Norfolk. Upon arrival in Rotterdam the animals were caged in groups of 4 in a colony room in which only artificial (fluorescent) lighting was available. At this time lights were on between 04:00 and 12:00 h (short photoperiod). In September or October some groups of females were transferred to another colony room where the lights were on between 20:00 and 12:00 h (long photoperiod). Of the females placed into the long photoperiod, only those which showed full swelling of the vulva within 8 weeks were used in the experiment. Previous research has shown that in our colony anoestrous ferrets exposed to long days remained in oestrus for 10-45 weeks (Baum, 1976). In the present experiments all ferrets were bilaterally ovariectomized, using sodium pentobarbitone anaesthesia $(35 \mathrm{mg} / \mathrm{kg}$ ), 2-3 weeks after full vulval swelling was achieved and were killed 3-5 weeks later. Pairs of oestrous and anoestrous females were always matched so that they were ovariectomized and killed on the same days.

\section{Steroids}

$\left[2,4,6,7-{ }^{3} \mathrm{H}\right]$ Oestradiol- $17 \beta$ (sp. act. $115 \mathrm{Ci} / \mathrm{mmol}$ : Radiochemical Centre, Amersham, England) was purified on Sephadex LH-20 columns prior to use (Wu \& Lundy, 1971). Unlabelled oestradiol (Steroloids Inc.) was used without further purification.

\section{Tissue preparation}

Ferrets were always killed between 12:00 and 14:00 h just after the onset of darkness in the colony. Each animal was deeply anaesthetized with sodium pentobarbitone before being decapitated. A sample of trunk blood was collected into a cold heparinized tube, centrifuged at $4{ }^{\circ} \mathrm{C}$, and the plasma was stored at $-20^{\circ} \mathrm{C}$. The brain was quickly removed from the skull, and after the removal of any adhering blood clots the following dissection was performed with the ventral surface of the brain facing upwards on an ice-cold glass plate: two frontal cuts were made, one just rostral to the optic chiasma and another at the caudal edge of the mammillary bodies. This block of tissue was turned on end and the base of the brain was isolated by making a cut at the level of the anterior commissure. This slice of tissue was laid flat and the entire hypothalamus plus preoptic region (designated hypothalamus) were dissected out by making cuts along the two lateral fissures. The two lateral pieces of tissue,consisting of amygdala and overlying cortex, were divided in half by single sagittal cuts, and the resulting two medial pieces of tissue were pooled and designated amygdala (including overlying cortex). An additional frontal cut was made $3 \mathrm{~mm}$ caudal to the posterior border of the mammillary bodies, overlying pieces of cortex were dis- 
carded, and the remaining tissue was designated midbrain. A piece of medial parietal cortex was dissected out, and the entire pituitary gland was removed from the sella turcica without separating the anterior and posterior lobes. Finally, the entire uterus was dissected free of connective tissue and fat. All tissues were kept ice-cold following dissection.

Uterine samples were minced with fine scissors. This tissue, and the different brain regions and pituitary were homogenized in glass tubes using 20 strokes of a teflon pestle in appropriate volumes of ice-cold TEM-buffer (10 mM-Tris, $1.5 \mathrm{mm-EDTA,} 1.4 \mathrm{~mm}$-mercaptoethanol, $0.02 \%$

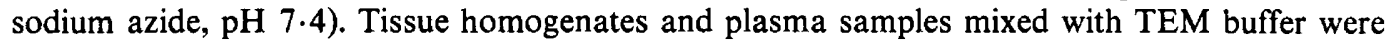
centrifuged at $130000 \mathrm{~g}$ for $20 \mathrm{~min}$ in a Beckman Airfuge which together with its air supply was kept in a cold room at $4^{\circ} \mathrm{C}$. The supernatants were saved. A $50 \mu \mathrm{l}$ aliquot from each sample was frozen for later determination of protein concentration (Lowry, Rosebrough, Farr \& Randall, 1951), and the remaining material was treated as described below.

\section{Estimating specific binding of oestradiol}

Tissue samples from 4 ferrets in each endocrine condition were assayed separately using methods adapted from those described by Vreeburg, Schretlen \& Baum (1975). Following ultracentrifugation, $200 \mu \mathrm{l}$ volumes of cytosol from each sample were incubated with $1.2 \mathrm{nM}$ $\left[{ }^{3} \mathrm{H}\right]$ oestradiol for $18 \mathrm{~h}$ at $4{ }^{\circ} \mathrm{C}$ to determine the total amount of binding present. A duplicate aliquot from the same sample was incubated with $\left[{ }^{3} \mathrm{H}\right]$ oestradiol plus a 100 -fold molar excess of unlabelled oestradiol in order to estimate the amount of non-specific binding present. After incubation, a $50 \mu \mathrm{l}$ aliquot was taken and used only to check for proper labelling. The bound and unbound oestradiol remaining in each tube were separated by adding $500 \mu \mathrm{l}$ of a suspension of dextran-coated charcoal $(0.025 \%$ dextran T-70 and $0.25 \%$ Norit A charcoal prepared in 10 $\mathrm{mM}$-Tris buffer containing $0.02 \%$ sodium azide, $\mathrm{pH} 7.4$ ) and centrifuging at $4^{\circ} \mathrm{C}$ for $10 \mathrm{~min}$ at $2000 \mathrm{~g}$. Subsequently $500 \mu \mathrm{l}$ of the supernatant, which contained the bound oestradiol, was pipetted into counting vials. A toluene-based scintillation cocktail $(16 \mathrm{ml})$ was added to all vials, which were counted in a Packard Tri-carb 3375 liquid scintillation spectrometer for 5 min with an efficiency for tritium of approximately $25 \%$. Conversion of the resulting counts to disintegrations per minute (d.p.m.) was carried out using the external standard ratio method. For each tissue sample the amount of specifically bound $\left[{ }^{3} \mathrm{H}\right]$ oestradiol was calculated by subtracting the amount of non-specifically bound $\left[{ }^{3} \mathrm{H}\right]$ oestradiol from the total amount of bound $\left[{ }^{3} \mathrm{H}\right]$ oestradiol, and the results were expressed as fmol oestradiol bound/mg cytosol protein.

\section{Estimating affinity of hypothalamic cytosols for oestradiol}

Hypothalamic samples from 4 ferrets were pooled for each determination. Following homogenization and ultracentrifugation, aliquots of $200 \mu$ cytosol were incubated for $18 \mathrm{~h}$ at $4^{\circ} \mathrm{C}$ with increasing concentrations $(0.046-1.2 \mathrm{nM})$ of $\left[{ }^{3} \mathrm{H}\right]$ oestradiol. Two additional aliquots were incubated with $1.2 \mathrm{nM}-\left[{ }^{3} \mathrm{H}\right]$ oestradiol plus a 100 -fold molar excess of unlabelled oestradiol, and the results obtained were later used to correct for non-specific binding of oestradiol present in each sample (Chamness \& McGuire, 1975). Following incubation, a $50 \mu \mathrm{l}$ aliquot was taken from each sample in which to determine the total amount of bound plus unbound $\left[{ }^{3} \mathrm{H}\right]$ oestradiol present. Bound and unbound $\left[{ }^{3} \mathrm{H}\right]$ oestradiol were then separated in each sample using dextrancoated charcoal as already described, and $500 \mu \mathrm{l}$ of the resulting supernatant together with the $50 \mu \mathrm{l}$ aliquot collected previously were counted for $40 \mathrm{~min}$. The counts obtained were converted to d.p.m. using the external standard ratio method, and these values were in turn converted to $\mathrm{pmol} / \mathrm{l}$ solution. The concentration of specifically bound oestradiol (Bsp) present at each ligand concentration was calculated by (a) multiplying the unbound ligand concentration (U) at each point by the mean bound/unbound ratio for the two samples containing $1.2 \mathrm{~nm}-\left[{ }^{3} \mathrm{H}\right]$ oestradiol plus $120 \mathrm{nm-unlabelled} \mathrm{oestradiol,} \mathrm{and} \mathrm{(b)} \mathrm{subtracting} \mathrm{this} \mathrm{value} \mathrm{from} \mathrm{the} \mathrm{total} \mathrm{measured} \mathrm{binding}$ at each ligand concentration (Chamness \& McGuire, 1975). Subsequently, Bsp was plotted 
against Bsp/U at each ligand concentration (Scatchard, 1949) and the best-fit line was determined using the method of least squares.

\section{Results and Discussion}

In each of the tissues studied the capacity to bind oestradiol specifically did not differ between ferrets which were ovariectomized while in or out of oestrus (Table 1). The oestradiol binding capacity of the uterus was at least 10 times greater than that of any other tissue analysed. When the data for non-uterine tissues from oestrous and anoestrous females were combined and subjected to a Kruskal-Wallis 1-way analysis of variance (Siegel, 1956), an overall significant difference was obtained $(H=35.59, P<0.01)$. Individual comparisons between tissue samples were made using 2-tailed Mann-Whitney U tests (Siegel, 1956), and they showed that oestradiol binding capacity was significantly higher in pituitary cytosols than in cytosols from any brain region $(P<0.025)$ or in blood plasma $(P<0.01)$. The binding capacities of hypothalamus, amygdala, and midbrain were significantly greater than those of cerebral cortex $(P<0.025)$ or blood plasma $(<0.01)$. Oestradiol binding in the hypothalamus was significantly higher than in the amygdala $(P<0.025)$, but not greater than the midbrain. The capacity of the amygdala and midbrain to bind oestradiol did not differ significantly; however, the difference between cortical and plasma binding was significant $(P<0.025)$.

Table 1. Specific binding capacity for oestradiol in cytosols from uterus, pituitary and several brain regions of female ferrets ovariectomized while in oestrus or anoestrus

\begin{tabular}{lcc}
\hline \multicolumn{1}{c}{ Tissue } & Oestrus $(\mathrm{N}=4)$ & Anoestrus $(\mathrm{N}=4)$ \\
\hline Uterus & $101.0 \pm 14.0$ & $110.0 \pm 22.0$ \\
Pituitary & $12.8 \pm 4 \cdot 1$ & $14.0 \pm 4.7$ \\
Hypothalamus & $6.6 \pm 1.7$ & $6.6 \pm 1.5$ \\
Amygdala & $3.5 \pm 0.7$ & $3.8 \pm 0.7$ \\
Midbrain & $4.8 \pm 1.0$ & $5.2 \pm 0.9$ \\
Cerebral cortex & $2.3 \pm 0.3$ & $1.4 \pm 0.9$ \\
Blood plasma & 0 & 0 \\
\hline
\end{tabular}

Data are expressed as mean $( \pm$ s.e.m.) fmol oestradiol bound/mg protein.

No evidence was obtained to suggest that the affinity of hypothalamic receptors for oestradiol differed in ferrets which were ovariectomized while in oestrus or anoestrus. Scatchard plot representations of the results of one such experiment are shown in Text-fig. 1. The association constants $\left(K_{\mathrm{a}}\right)$ obtained in both groups are characteristic of high-affinity steroidreceptor complexes (Jensen \& DeSombre, 1973). In the initial experiment (Text-fig. 1) the apparent $K_{\mathrm{a}}$ was slightly higher in hypothalamic cytosols collected from anoestrous females; however, when this experiment was repeated just the reverse outcome was obtained, with the $K_{\mathrm{a}}$ in anoestrous animals being $7.7 \times 10^{10} \mathrm{M}^{-1}(4.4 \mathrm{mg}$ protein/ml) and that in oestrous females being $9.9 \times 10^{10} \mathrm{M}^{-1}(3.9 \mathrm{mg}$ protein $/ \mathrm{ml})$.

The present findings give no indication that changes in the cytoplasmic binding of oestradiol in the ferret brain are associated with the occurrence of oestrus. Similar biochemical results have been obtained in another laboratory (M. Klinowska, personal communication). These findings, together with those of Morrell et al. (1977) for the mink, suggest that a change in the binding capacity or affinity of hypothalamic receptors for oestradiol does not underlie the resetting of the brain "gonadostat" which has been postulated to explain the occurrence of oestrus in seasonal breeders. 

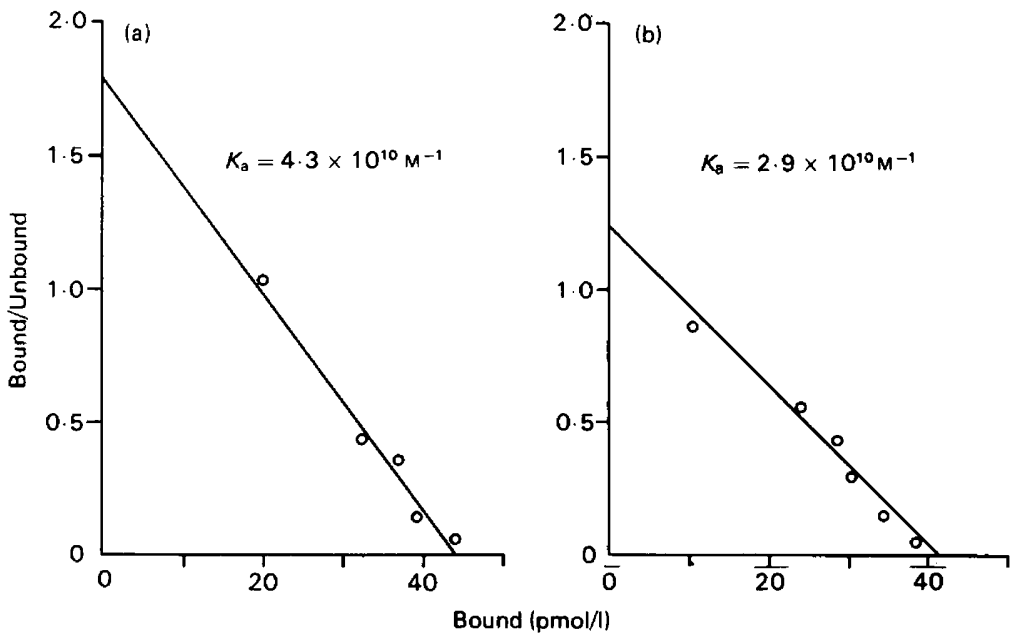

Text-fig. 1. Scatchard plot representations of the binding affinity for oestradiol of hypothalmic cytosols pooled from groups of 4 female ferrets which were ovariectomized while (a) in anoestrus $(6.5 \mathrm{mg}$ protein $/ \mathrm{ml})$ or (b) in oestrus $(4.7 \mathrm{mg}$ protein $/ \mathrm{ml})$. The association constants $\left(K_{\mathrm{a}}\right)$ shown were calculated from these particular plots.

This work was supported by a pool-position grant from the Erasmus University. We are indebted to Dr J. Herbert for useful discussions prior to the inception of this work. The technical help of F. Vels and of J. van Ophemert are gratefully acknowledged.

\section{References}

Baum, M.J. (1976) Effects of testosterone propionate administered perinatally on sexual behavior of female ferrets. J. comp. Physiol. Psychol. 90, 399-410.

Bissonette, T.H. (1932) Modification of mammalian sexual cycles; reactions of ferrets of both sexes to electric light added after dark in November and December. Proc. $R$. Soc. B 110, 322-336.

Chamness, G.C. \& McGuire, W.L. (1975) Scatchard plots: common errors in correction and interpretation. Steroids 26, 538-542.

Donovan, B.T. (1967) The feedback action of ovarian hormones in the ferret. J. Endocr. 38, 173-179.

Donovan, B.T. \& van der Werff Ten Bosch, J.J. (1965) Physiology of Puberty. Arnold, London.

Hammond, J., Jr (1954) Light Regulation of hormone secretion. Vitams Horm. 12, 157-206.

Jensen, E.V. \& DeSombre, E.R. (1973) Estrogen receptor interaction. Science, N.Y. 182, 126134.

Lowry, O.H., Rosebrough, N.J., Farr, A.L. \& Randall, R.J. (1951) Protein measurement with the folin phenol reagent. J. biol. Chem. 193, 265-275.
Morrell, J.I., Ballin, A., \& Pfaff, D.W. (1977) Autoradiographic demonstration of the pattern of $\left[{ }^{3} \mathrm{H}\right]$, estradiol-concentrating cells in the brain of a carnivore, the mink (Mustela vison). Anat. Rec. 189, $609-623$.

Scatchard, G. (1949) The attraction of proteins for small molecules and ions. Ann. N.Y. Acad. Sci. 51, 660-667.

Siegel, S. (1956) Nonparametric Statistics for the Behavioral Sciences. McGraw-Hill, New York.

Vreeburg, J.T.M., Schretlen, P.J.M. \& Baum, M.J. (1975) Specific, high-affinity binding of $17 \beta$-estradiol in cytosols from several brain regions and pituitary of intact and castrated adult male rats. Endocrinology 97, 969-977.

Wise, P.M., Payne, A.H., Karsch, F.J. \& Jaffe, R.B. (1975) Cytoplasmic oestrogen receptor complex of female ovine pituitary: changes associated with the reproductive state and oestradiol treatment. $J$. Endocr. 67, 447-452.

Wu, C.-H. \& Lundy, L.E. (1971) Radioimmunoassay of plasma estrogens. Steroids 18, 91-98. 